\title{
Mortality of workers in an automobile engine and parts manufacturing complex
}

\author{
J E VENA, H A SULTZ, R C FIEDLER, AND R E BARNES \\ From the Research Program in Occupational and Environmental Health, Department of Social and \\ Preventive Medicine, State University of New York at Buffalo, Buffalo, New York 14214, USA
}

ABSTRACT A proportionate mortality ratio (PMR) study was conducted using data on workers from three local unions representing an integrated automobile factory composed of forge, foundry, and engine (machine and assembly) plants. Ninety four percent of the death certificates were obtained for all active and non-active workers who died during the period 1 January 1970 to 31 December 1979 and were vested in union and company benefit programmes. Observed numbers of deaths were compared with expected numbers based on two standards, the proportionate mortality among men in the United States 1970-9 and among men in Erie County 1975. There was close agreement between the number of observed and expected deaths by either standard of comparison among white auto workers in the forge and foundry plants. Valid analyses of cause specific mortality among non-whites could be conducted for the foundry plant only. Although there was raised PMR for deaths due to diseases of the circulatory system using the Erie County standard, none of the other cause specific PMRs was significant. Although based on small numbers, the risk of cancer of the lung was significantly high in non-whites under age 50 in the foundry $(P M R=2.6 ; p<0.05)$. The cause specific PMRs for whites in the engine plant were statistically significant for malignant neoplasms $(1 \cdot 2)$ and all external causes $(0.62)$ based on the US white male standard. Analysis of cancer specific mortality among white men in the machining/assembly plant showed significant excesses for cancer of the digestive system (PMR= $1.5)$, particularly of the liver $(P M R=2 \cdot 6)$ and pancreas $(P M R=1.9)$; cancers of the respiratory system $(P M R=1.4$ using the Erie County standard); and cancer of the urinary bladder $(P M R=$ $2 \cdot 3)$. Workers employed for more than 20 years showed statistically increased mortality ratios for cancers of the digestive system (1.9), particularly cancer of the pancreas (2.3) and cancer of the rectum (2.8). Individuals whose employment began during or before 1950 exhibited increased PMRs for cancers of the digestive organs $(1 \cdot 8)$, particularly of the pancreas $(2 \cdot 5)$ and of the bladder (3.4). Workers whose employment began after 1950 , on the other hand, exhibited raised PMRs for cancers of the respiratory system $(1 \cdot 5)$ and of the kidney $(3 \cdot 2)$. Since the foundry and forge plants did not start production until 1955, mortality associated with those work settings may be greater in the future.

A ten year mortality study of the workers from three local unions representing an automobile engine and parts factory complex located in Erie County, New York, was started as a result of the concern expressed by the health and safety representatives of the Western New York United Auto Workers. Three basic functions in the manufacture of automobile engines and parts took place in the industrial

Received 23 January 1984

Accepted 20 February 1984 complex under investigation: the casting of various metal parts in a foundry, the forging of parts, and the final machining and assembly of engines.

\section{Background}

The engine plant was established in 1938 with manufacturing operations entailing front and rear axle assemblies and automobile engines. War production expanded employment from 1900 in 1938 to more than 7800 employees in 1943 for the manufacture of Pratt and Whitney engines. In 1980 over 50 
departments were machining and assembling four different engine types. Although production has changed over the years, the methods of machining and assembly are similar. The metal casting plant or foundry, which began operations in 1954 and employed 2800 workers by 1980 , produced engine blocks and other miscellaneous automotive parts. The forge plant which began operation in $1954 \mathrm{em}-$ ployed 900 workers by 1971 . Production included sheering, rolling, and pressing of steel billets into automotive parts.

\section{Materials and methods}

Union records, the primary source of data for this study, were maintained to determine vesting privileges, seniority rights, and eligibility for pension benefits. In addition, the company notified local unions in writing of personnel changes, including deaths of active workers, and, through the benefits department of the company, of the deaths of retired workers. Nevertheless, data on birth dates, job titles, and job mobility were unobtainable for most of the work force. In addition, detailed occupational histories were not available, this limiting knowledge of occupational exposures to those generally associated with the industrial processes common to the function of each plant. Owing to the limitations, a retrospective cohort study was not feasible and so use was made of proportionate mortality ratios (PMRs). ${ }^{12}$ PMRs have been shown to be relatively effective for estimating cause specific risk and are often used to determine differential mortality. ${ }^{23}$ Although somewhat limited, PMR analyses have been shown to approximate standard mortality ratio (SMR) analyses when the same data are used, and thus are useful for generating hypotheses related to cause specific mortality when limited data are available.

Verification of deaths was pursued through three other sources. The death lists obtained from local union records were sent to the social security department of the International Union (UAW) for verification. An additional 51 deaths that had occured among pensioned workers and were not known to the union were identified by the International Union. The employment records of these workers were then verified and completed at the appropriate local union. In addition, each local union had an employee credit union, and records of death benefits paid from each credit union were cross referenced with the lists of deaths assembled from local and international sources. As a final step, corporate management of the industrial complex agreed to provide missing employment data for 70 individuals and to verify the vital status of several individuals whose records were not validated through other sources. Company data resulted in the elimination of 12 individuals from this study because one death occurred outside the study period, six occurred among workers who had fewer than 10 years of service, and five individuals were alive.

All workers, either active or non-active, who died during the period 1 January 1970 to 31 December 1979 , with at least 10 years from date of hire to date of termination, were selected for inclusion in the study. Duration of exposure was calculated within that period for each individual in the study by subtracting layoff and sick leave time from accumulated years of service.

A total of 821 records representing men who had died met the criteria for inclusion in the study. Death certificates for these workers were requested from the vital statistics departments of 18 states and Canada and 769 (93.7\%) were obtained. The underlying cause of death was coded by trained nosologists employed by the state of New York according to the rules in effect at the time of death. Cause of death was then recoded consistent with the eighth revision of the International Classification of Disease $^{4}$ whenever they were not in the eighth revision. The 74 out of state deaths were coded by one of the coinvestigators after training and consultation in nosology by the New York State Health Department. Observed numbers of deaths by cause among the 769 were compared with expected numbers based on the race, cause specific, and calendar year proportionate mortality among men in the United States.' Expected deaths were also calculated using race and cause specific relative frequencies for Erie County men, 1975. Differences between observed and expected numbers of deaths were summarised in the form of a proportionate mortality ratio (PMR). The statistical significance of the differences between observed and expected numbers was determined by chi-square tests with one degree of freedom.

\section{Findings}

Of the 769 auto workers who died within the study period, $635(83 \%)$ were white and $134(17 \%)$ non-white. The distributions by race and age at death are presented in tables 1 and 2 . About $10 \%$ of the white workers died before the age of 50 . The percentage of deaths among white foundry workers under 50 was considerably higher than among the employees of the other plants. Forty percent of all white workers were between 60 and 69 at the time of death. There was little variation by plant in the percentage of deaths at the older ages. Among non-white workers, over $26 \%$ of the deaths occur- 
Table 1 Mortality among white auto workers, by age at death and plant, 1970-9

\begin{tabular}{|c|c|c|c|c|c|c|c|c|}
\hline \multirow[t]{3}{*}{ Age at death } & \multicolumn{8}{|l|}{ Plant } \\
\hline & \multicolumn{2}{|c|}{ Engine } & \multicolumn{2}{|c|}{ Forge } & \multicolumn{2}{|c|}{ Foundry } & \multicolumn{2}{|c|}{ Total } \\
\hline & No & $\%$ & No & $\%$ & No & $\%$ & No & $\%$ \\
\hline $\begin{array}{l}30-39 \\
40-49 \\
50-59 \\
60-69 \\
\geqslant 70 \\
\text { Total }\end{array}$ & $\begin{array}{r}4 \\
40 \\
120 \\
188 \\
120 \\
472\end{array}$ & $\begin{array}{r}0.8 \\
8.5 \\
25.4 \\
39.8 \\
25.5 \\
100.0\end{array}$ & $\begin{array}{r}-3 \\
17 \\
28 \\
11 \\
59\end{array}$ & $\begin{array}{r}- \\
5.1 \\
28.8 \\
47.5 \\
18 \cdot 6 \\
100 \cdot 0\end{array}$ & $\begin{array}{r}4 \\
15 \\
29 \\
37 \\
19 \\
104\end{array}$ & $\begin{array}{r}3.8 \\
14.4 \\
27.9 \\
35.6 \\
18.3 \\
100.0\end{array}$ & $\begin{array}{r}8 \\
58 \\
166 \\
253 \\
150 \\
635\end{array}$ & $\begin{array}{r}1 \cdot 2 \\
9.1 \\
26.2 \\
39.9 \\
23.6 \\
100.0\end{array}$ \\
\hline
\end{tabular}

Table 2 Mortality among non-white auto workers, by age at death and plant, 1970-9

\begin{tabular}{|c|c|c|c|c|c|c|c|c|}
\hline \multirow[t]{3}{*}{ Age at death } & \multicolumn{8}{|c|}{ Plant } \\
\hline & \multicolumn{2}{|c|}{ Engine } & \multicolumn{2}{|c|}{ Forge } & \multicolumn{2}{|c|}{ Foundry } & \multicolumn{2}{|c|}{ Total } \\
\hline & No & $\%$ & No & $\%$ & No & $\%$ & No & $\%$ \\
\hline $\begin{array}{l}30-39 \\
40-49 \\
50-59 \\
60-69 \\
\geqslant 70 \\
\text { Total }\end{array}$ & $\begin{array}{r}-1 \\
6 \\
13 \\
17 \\
37\end{array}$ & $\begin{array}{r}- \\
2.7 \\
16.2 \\
35.2 \\
45.9 \\
100.0\end{array}$ & $\begin{array}{r}- \\
2 \\
3 \\
4 \\
2 \\
11\end{array}$ & $\begin{array}{r}- \\
18 \cdot 2 \\
27 \cdot 3 \\
36 \cdot 4 \\
18 \cdot 2 \\
100 \cdot 0\end{array}$ & $\begin{array}{r}8 \\
25 \\
26 \\
22 \\
5 \\
86\end{array}$ & $\begin{array}{r}9.3 \\
29.1 \\
30.2 \\
25.6 \\
5.8 \\
100.0\end{array}$ & $\begin{array}{r}8 \\
28 \\
35 \\
39 \\
24 \\
134\end{array}$ & $\begin{array}{r}5.9 \\
20.8 \\
26.2 \\
29.2 \\
17.9 \\
100.0\end{array}$ \\
\hline
\end{tabular}

Table 3 Mortality among white auto workers in the engine plant, by underlying cause of death, 1970-9

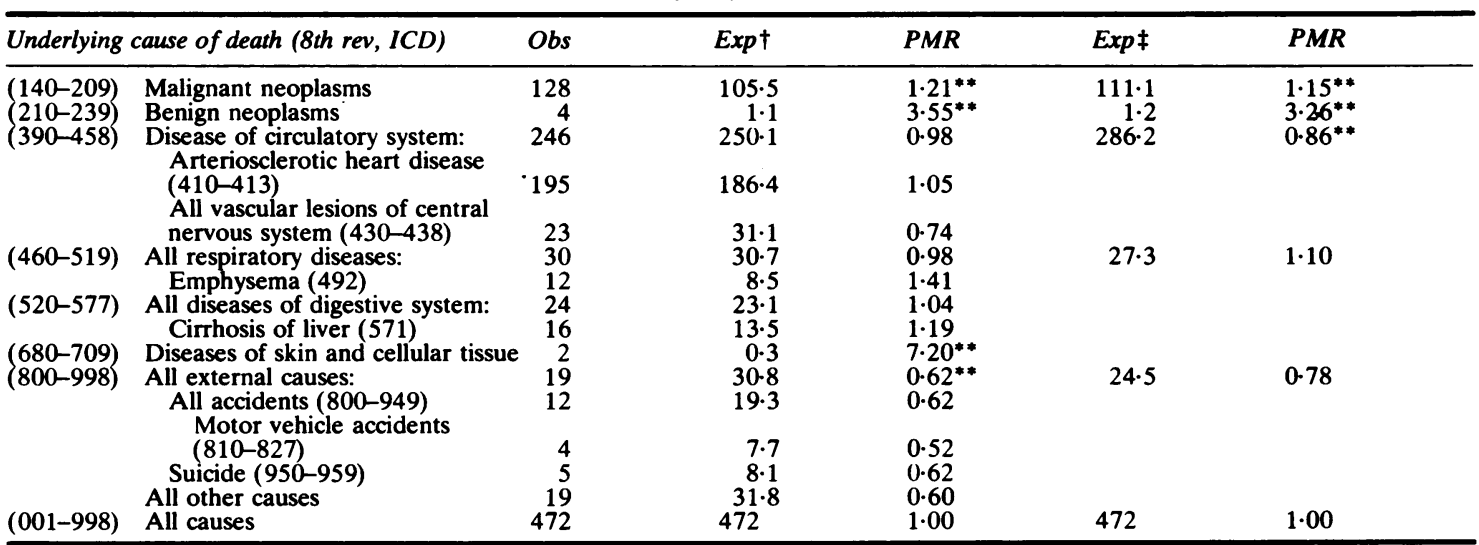

** Significant at the $0.05 \alpha$ level.

$\dagger$ Expected deaths based on proportionate mortality for US white men, 1970-9.

$\ddagger$ Expected deaths based on proportionate mortality for Erie County white men, 1975.

red before the age of 50 , and more than $20 \%$ of the deaths before 50 occurred before age 40 .

The cause specific PMRs for whites in the engine plant (table 3) indicate a statistically significant raised risk of malignant neoplasms, benign neoplasms, and diseases of the skin and cellular tissues; a statistically significant deficit was found in mortality from all external causes, based on the US white male standard. The slightly increased risk for malignant neoplams was upheld using the Erie County standard, whereas the significant low risk for all external causes shifted to diseases of the circulatory system when the Erie County standard was applied.

The mortality experience of white auto workers at the forge plant is shown in table 4 . There was close agreement between the number of observed and expected deaths by either standard of comparison. The statistically significant raised PMRs for benign neoplasms and motor vehicle accidents were based on very small numbers and must be interpreted with caution. The mortality experience of white workers in the foundry plant (not presented in a table) 
showed no significant deviations from the expected distribution of deaths by cause.

Valid analyses of cause specific mortality among non-whites could not be conducted in the forge and engine plants because of the small number of deaths. Table 5, however, presents the analysis of cause specific deaths among non-whites employed in the foundry. Although there was a raised PMR for deaths due to diseases of the circulatory system when the Erie County comparison population was used, none of the other cause specific PMRs was significant. Although not statistically significant, the PMR for lung cancer among non-whites in the foundry was about $1 \cdot 5$, which is consistent with the findings of other studies. The high proportion of deaths in the younger non-white age groups prompted an analysis of cause specific mortality among workers who died before reaching 50 years of age. No significant findings related to cause of death were observed except for cancer of the lung for which a PMR of $2.59(\mathrm{p}<0.05)$ was obtained. The finding was based on relatively few deaths, however, four observed, 1.5 expected.

Analysis of cancer specific mortality among white men in the engine plant was conducted to ascertain the specific cancer sites contributing to the raised PMR for all malignant neoplasms combined in that occupational group. Mortality from specific cancer sites is shown in table 6 and reflects significant excesses for cancers of the digestive system, particularly of the liver and pancreas; cancers of the respiratory system (using the Erie County standard); and cancer of the urinary bladder. By contrast, no statistically significant differences between

Table 4 Mortality among white auto workers in the forge plant, by underlying cause of death, 1970-9

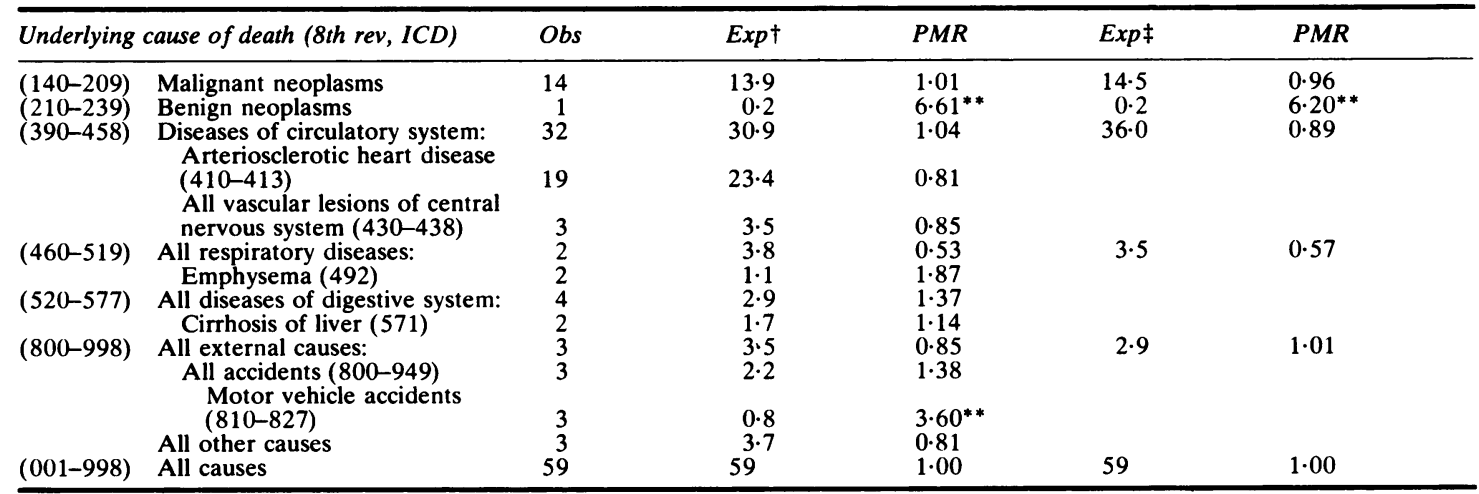

** Significant at the $0.05 \alpha$ level.

$\dagger$ Expected deaths based on proportionate mortality for US white men, 1970-9.

$¥$ Expected deaths based on proportionate mortality for Erie County white men, 1975.

Table 5 Mortality among non-white auto workers in the foundry plant, by underlying cause of death, 1970-9

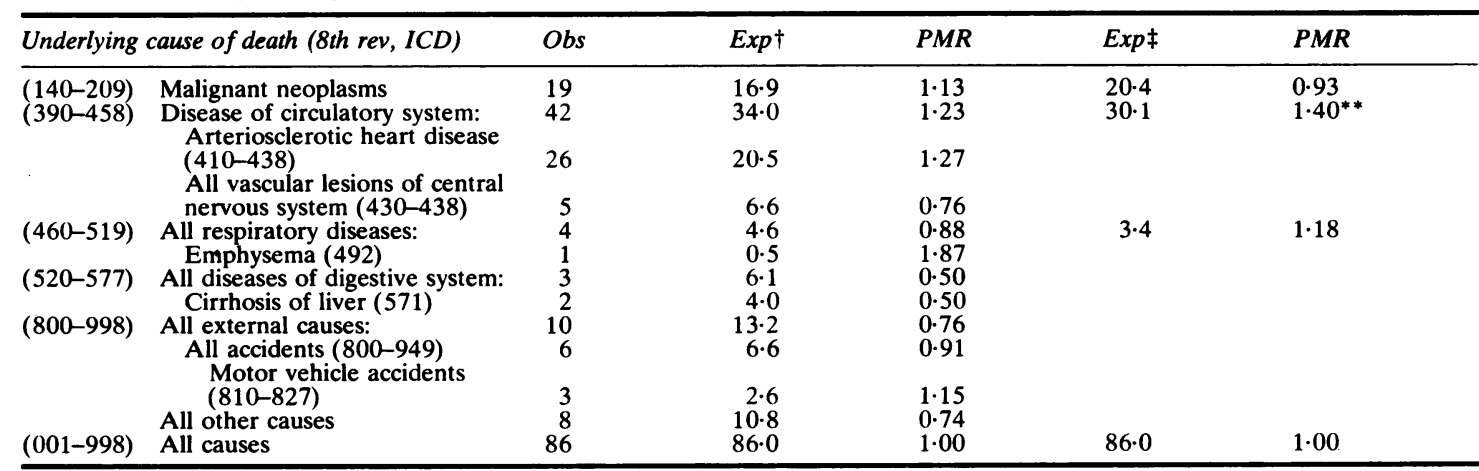

** Significant at the $0.05 \alpha$ level.

$\dagger$ Expected deaths based on proportionate mortality for US non-white men, 1970-9.

¥ Expected deaths based on proportionate mortality for Erie County non-white men, 1975. 
Table 6 Mortality among white auto workers in the engine plant, by site of malignant neoplasm, 1970-9

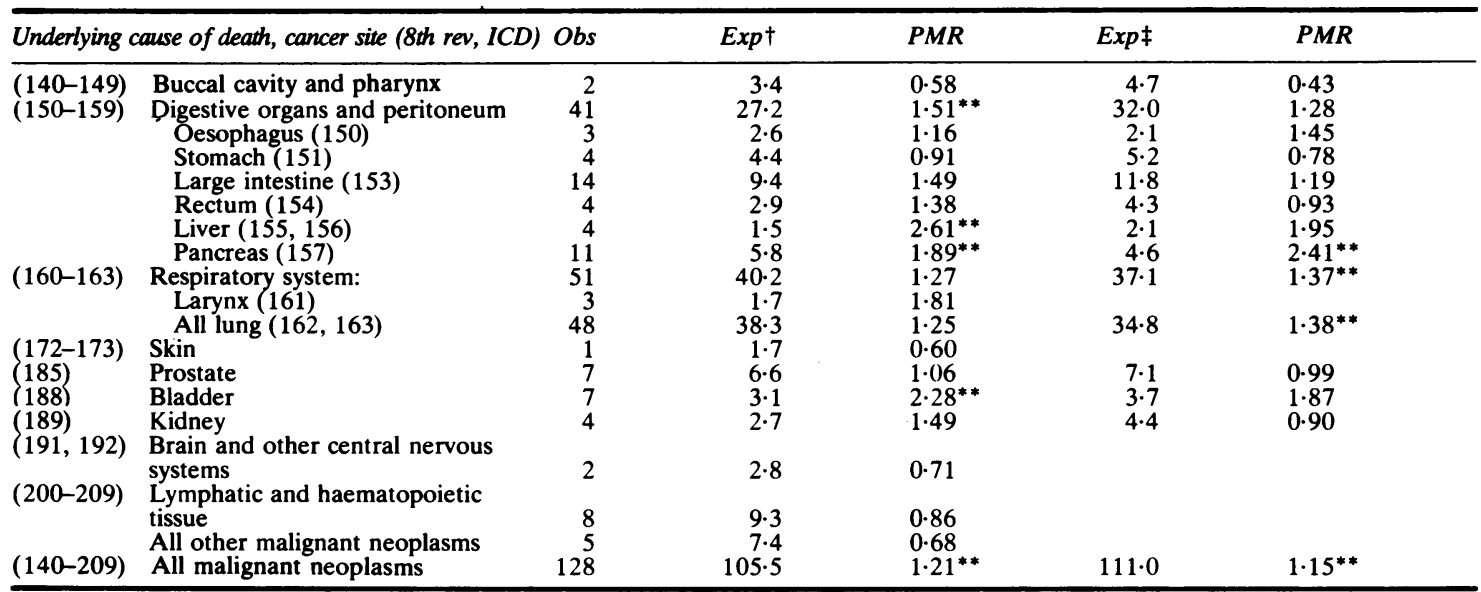

** Significant at the $0.05 \alpha$ level.

$\dagger$ Expected deaths based on proportionate mortality for US white men, 1970-9.

¥ Expected deaths based on proportionate mortality for Erie County white men, 1975.

Table 7 Mortality among white auto workers in the engine plant, by site of malignant neoplasm and number of years employed, 1970-9

\begin{tabular}{|c|c|c|c|c|c|c|c|c|c|c|c|}
\hline \multicolumn{2}{|c|}{ Underlying cause of death, cancer site (8th rev, ICD) } & \multicolumn{10}{|c|}{ No of years employed } \\
\hline & & \multicolumn{5}{|c|}{$\leqslant 20$ years } & \multicolumn{5}{|c|}{$>20$ years } \\
\hline & & Obs & $\operatorname{Exp} \dagger$ & $P M R$ & $\operatorname{Exp} \ddagger$ & $P M R$ & Obs & $\operatorname{Exp} \dagger$ & $P M R$ & $\operatorname{Exp} \ddagger$ & $P M R$ \\
\hline \multirow{8}{*}{$\begin{array}{l}(140-149) \\
(150-159)\end{array}$} & Buccal cavity and pharynx & 1 & 1.6 & $0 \cdot 64$ & $2 \cdot 2$ & 0.44 & 1 & 1.9 & 0.53 & $2 \cdot 4$ & 0.42 \\
\hline & Digestive organs and peritoneum & 15 & $13 \cdot 4$ & $1 \cdot 12$ & $15 \cdot 4$ & 0.97 & 26 & $13 \cdot 8$ & $1.88^{* *}$ & $16 \cdot 6$ & $1.57^{* *}$ \\
\hline & Oesophagus (150) & 1 & $1 \cdot 2$ & 0.84 & 1.0 & 0.97 & 2 & 1.4 & 1.43 & 1.0 & 1.93 \\
\hline & Stomach (151) & 1 & $2 \cdot 2$ & 0.45 & $2 \cdot 3$ & 0.43 & 3 & $2 \cdot 2$ & 1.37 & $2 \cdot 8$ & 1.07 \\
\hline & Large intestine (153) & 6 & 4.7 & $1 \cdot 28$ & 5.8 & $1 \cdot 03$ & 8 & 4.7 & 1.70 & 5.9 & 1.35 \\
\hline & Rectum (154) & - & - & - & - & - & 4 & 1.5 & $2.76^{* *}$ & $2 \cdot 2$ & 1.86 \\
\hline & Liver $(155,156)$ & 2 & 0.8 & $2 \cdot 67$ & $1 \cdot 0$ & 1.91 & 2 & 0.8 & 2.56 & 1.0 & 1.99 \\
\hline & Pancreas (157) & 4 & $2 \cdot 8$ & $1 \cdot 42$ & $2 \cdot 2$ & $1 \cdot 81$ & 7 & $3 \cdot 0$ & $2 \cdot 32^{* *}$ & $2 \cdot 4$ & $2.97^{* *}$ \\
\hline \multirow[t]{2}{*}{$(160-163)$} & Respiratory system: & 22 & $\begin{array}{r}18.5 \\
0.8\end{array}$ & $1 \cdot 19$ & $17 \cdot 3$ & $1 \cdot 27$ & 29 & $21 \cdot 7$ & $1 \cdot 33$ & $19 \cdot 8$ & $1 \cdot 47^{* *}$ \\
\hline & All lung $(162,163)$ & 19 & $\begin{array}{r}0.0 \\
17 \cdot 6\end{array}$ & $\begin{array}{l}3.93 \\
1.08\end{array}$ & $16 \cdot 0$ & $1 \cdot 19$ & $\overline{29}$ & $\overline{20} \cdot 7$ & $\overline{1.40}$ & $18 \cdot 8$ & 54 \\
\hline$(172-173)$ & Skin & - & - & - & - & - & 1 & 0.9 & 1.16 & & \\
\hline$(185)$ & Prostate & 5 & $3 \cdot 8$ & $1 \cdot 31$ & $4 \cdot 2$ & $1 \cdot 18$ & 2 & $2 \cdot 8$ & 0.72 & $2 \cdot 8$ & 0.70 \\
\hline$(188)$ & Bladder & 3 & 1.6 & 1.85 & $2 \cdot 1$ & 1.42 & 4 & $1 \cdot 5$ & 2.76 & 1.6 & $2 \cdot 46$ \\
\hline$(189)$ & Kidney & 4 & $1 \cdot 3$ & $3 \cdot 21^{* *}$ & $2 \cdot 1$ & $1 \cdot 96$ & - & - & - & - & 一 \\
\hline$(1$ & $\begin{array}{l}\text { Brain and other central nervous } \\
\text { system }\end{array}$ & 2 & $1 \cdot 3$ & 1.57 & & & - & - & - & - & - \\
\hline$(200-209)$ & Lymphatic and haematopoietic & & & & & & & & & & \\
\hline & tissue & 4 & $4 \cdot 6$ & $0 \cdot 87$ & & & 4 & $4 \cdot 7$ & $0 \cdot 85$ & & \\
\hline & All other malignant neoplasms & 3 & $\begin{array}{r}3 \cdot 6 \\
50 \cdot 0\end{array}$ & $0 \cdot 84$ & & & 2 & $\begin{array}{r}3 \cdot 8 \\
5\end{array}$ & $0 \cdot 52$ & & \\
\hline$(140-209)$ & All malignant neoplasms & 59 & $50 \cdot 9$ & $1 \cdot 16$ & $54 \cdot 0$ & 1.09 & 69 & $54 \cdot 5$ & $1 \cdot 26^{* *}$ & $57 \cdot 0$ & $1 \cdot 22^{* *}$ \\
\hline
\end{tabular}

** Significant at the $0.05 \alpha$ level.

$\dagger$ Expected deaths based on proportionate mortality for US white men, 1970-9.

¥ Expected deaths based on proportionate mortality for Erie County white men, 1975.

observed and expected deaths were found for any cancer sites among white workers in the forge and foundry plants.

Tables 7 and 8 show an analysis of cancer specific mortality among whites in the engine plant by number of years employed and year of first emp- loyment. Workers employed for more than 20 years showed statistically increased mortality ratios for cancers of the digestive system, especially cancer of the pancreas. When the Erie County standard was applied to generate expected numbers, workers employed for more than 20 years also showed raised 
Table 8 Mortality among white auto workers in the engine plant, by site of malignant neoplasm and year of first employment, 1970-9

\begin{tabular}{|c|c|c|c|c|c|c|c|c|c|c|c|}
\hline \multicolumn{2}{|c|}{ Underlying cause of death, cancer site (8th rev, ICD) } & \multicolumn{10}{|c|}{ Year of first employment } \\
\hline & & \multicolumn{5}{|c|}{ During or before 1950} & \multicolumn{5}{|c|}{ After 1950} \\
\hline & & Obs & $\operatorname{Exp} \dagger$ & $P M R$ & $\operatorname{Exp} \ddagger$ & $P M R$ & Obs & $\operatorname{Exp} \dagger$ & $P M R$ & $\operatorname{Exp} \ddagger$ & $\overline{P M R}$ \\
\hline \multirow{8}{*}{$\begin{array}{l}(140-149) \\
(150-159)\end{array}$} & Buccal cavity and pharynx & 1 & 1.8 & 0.54 & $2 \cdot 4$ & 0.41 & 1 & 1.6 & 0.62 & $2 \cdot 2$ & 0.44 \\
\hline & Digestive organs and peritoneum & 27 & $15 \cdot 0$ & $1.79^{* *}$ & 17.7 & $1.53^{* *}$ & 14 & $12 \cdot 2$ & 1.15 & $14 \cdot 4$ & 0.98 \\
\hline & Öesophagus (150) & 1 & 1.4 & 0.71 & $1 \cdot 1$ & 0.91 & 2 & $1 \cdot \overline{2}$ & 1.68 & 0.9 & $2 \cdot 08$ \\
\hline & Stomach (15i) & 3 & $2 \cdot 4$ & $1 \cdot 23$ & $2 \cdot 7$ & 1.09 & 1 & 1.9 & 0.51 & $2 \cdot 4$ & 0.41 \\
\hline & Large intestine (153) & 9 & $5 \cdot 2$ & 1.73 & $6 \cdot 6$ & 1.36 & 5 & $4 \cdot 2$ & $1 \cdot 20$ & $5 \cdot 2$ & 0.97 \\
\hline & Rectum ( & 4 & $1 . \overline{6}$ & $2 \cdot 47$ & $2 \cdot 4$ & 1.69 & - & - & & - & - \\
\hline & Liver $(155,156)$ & 2 & 0.9 & $2 \cdot 35$ & $1 \cdot 2$ & $1 \cdot 71$ & 2 & 0.7 & $2 \cdot 94$ & 0.9 & $2 \cdot 27$ \\
\hline & 157) & 8 & $3 \cdot 2$ & $2 \cdot 50^{* *}$ & $2 \cdot 5$ & $3 \cdot 19^{* *}$ & 3 & $2 \cdot 6$ & $1 \cdot 14$ & $2 \cdot 1$ & 1.45 \\
\hline \multirow{2}{*}{$(160-163)$} & $\begin{array}{l}\text { Respiratory system: } \\
\text { Larynx (161) }\end{array}$ & $\frac{24}{-}$ & $\frac{21 \cdot 5}{-}$ & $1 \cdot 11$ & $\underline{19 \cdot 8}$ & $\underline{1 \cdot 21}$ & $\begin{array}{r}27 \\
3\end{array}$ & $\begin{array}{r}18.7 \\
0.8\end{array}$ & $\begin{array}{l}1.45^{* *} \\
3.95^{* *}\end{array}$ & $17 \cdot 3$ & $1.56^{* *}$ \\
\hline & All lung $(162,163)$ & 24 & $20 \cdot 5$ & $1 \cdot 17$ & $18 \cdot 4$ & $1 \cdot 31$ & 24 & $17 \cdot 8$ & $1 \cdot 35$ & $16 \cdot 4$ & $1 \cdot 46^{* *}$ \\
\hline$(172-173)$ & Skin & 1 & $0 \cdot 8$ & $1 \cdot 21$ & & & - & - & - & - & - \\
\hline $\begin{array}{l}(185) \\
(188)\end{array}$ & $\begin{array}{l}\text { Prostate } \\
\text { Bladder }\end{array}$ & $\begin{array}{l}2 \\
6\end{array}$ & $\begin{array}{l}4 \cdot 0 \\
1.8\end{array}$ & $\begin{array}{l}0 \cdot 49 \\
3 \cdot 37^{* *}\end{array}$ & $\begin{array}{l}4 \cdot 3 \\
2 \cdot 3\end{array}$ & $\begin{array}{l}0.46 \\
2 \cdot 66^{* *}\end{array}$ & $\begin{array}{l}5 \\
1\end{array}$ & $\begin{array}{l}2 \cdot 6 \\
1 \cdot 3\end{array}$ & $\begin{array}{l}1.95 \\
0.77\end{array}$ & $\begin{array}{l}2 \cdot 8 \\
1 \cdot 5\end{array}$ & $\begin{array}{l}1 \cdot 81 \\
0.67\end{array}$ \\
\hline (189) & Kidney & , & - & - & & & 4 & $1 \cdot 3$ & $3 \cdot 16^{* *}$ & $2 \cdot 0$ & 1.97 \\
\hline 92) & $\begin{array}{l}\text { Brain and other central nervous } \\
\text { system: }\end{array}$ & 1 & 1.4 & 0.72 & & & 1 & 1.4 & 0.70 & & \\
\hline$(200-209)$ & Lymphatic and haematopoietic & & & & & & & & & & \\
\hline & tissue & 4 & $5 \cdot 0$ & $0 \cdot 81$ & & & 4 & $4 \cdot 4$ & $0 \cdot 91$ & & \\
\hline$(140-209)$ & All malignant neoplasms & 68 & $\begin{array}{r}4 \cdot 3 \\
57 \cdot 3\end{array}$ & $\begin{array}{l}0.45 \\
1.19\end{array}$ & $60 \cdot 1$ & $1 \cdot 13$ & $\begin{array}{r}3 \\
60\end{array}$ & $\begin{array}{r}3 \cdot 9 \\
48 \cdot 1\end{array}$ & $\begin{array}{l}0.77 \\
1.25^{* *}\end{array}$ & 50.8 & 1.18 \\
\hline
\end{tabular}

** Significant at the $0.05 \alpha$ level.

$\dagger$ Expected deaths based on proportionate mortality for US white men, 1970-9.

$¥$ Expected deaths based on proportionate mortality for Erie County white men, 1975.

PMRs for cancers of the respiratory system. Interestingly, workers employed for under 20 years had a raised PMR for cancer of the kidney, although this finding was not significant when the Erie County standard was applied. Individuals whose employment began during or before 1950 (table 8) showed increased mortality ratios for cancers of the digestive organs and in particular of the pancreas. The PMR for cancer of the bladder was also raised and significant for this group. Workers whose employment began after 1950, on the other hand, exhibited higher PMRs for cancers of the respiratory system and cancer of the kidney.

\section{Discussion}

\section{FORGE PLANT}

Excess mortality among the forge workers in this study was limited to benign neoplasms and motor vehicle accidents. These raised PMRs were based on very small numbers and must be interpreted with caution. In Long Term Mortality Study of Steel Workers $^{5}$ forge workers exhibited less than expected mortality when compared with the general population. Cause specific mortality was not reported, however. In an unpublished study (CK Redmond et al) findings indicated an excess incidence of stroke associated with oil mist or heat stress or both; the present study did not confirm that finding. Individual studies of forge workers to date have been limited in the capability to determine excess risk due to the small numbers of workers at risk and therefore the small numbers of observed deaths.

\section{FOUNDRY PLANT}

Compared with workers in the other plants, both white and non-white foundry workers showed a much higher percentage of deaths before age 50 . None of the cause specific PMRs for white men in the foundry plant was significant, however, and only the PMR for diseases of the circulatory system was slightly raised and significant for non-white men when the Erie County standard was applied. The most detailed mortality study of iron foundry workers to date showed an excess of lung cancer mortality that was highest among moulders and casters. ${ }^{6} \mathrm{~A}$ recent case control study nested in a proportional mortality study suggests a particularly high risk of lung cancer for men under 65 working in iron foundries. ${ }^{7}$ Although based on only four deaths, our study suggests that non-whites under 50 had an excess risk of lung cancer. Since this particular foundry did not start production until 1955, and since workers whose employment began after 1960 would not meet the 20 year or more latency requirement of lung cancer until 1980 and beyond, mortality associated with this setting may be greater in the future.

\section{ENGINE PLANT}

Unlike the other plants in the industrial complex, 
the engine plant was established in 1938, and the work force was much larger than the forge or foundry work forces. During the study period, $509(66 \%)$ of the observed deaths in the industrial complex were among members of the local union representing the engine plant. These findings suggested raised risk for all malignant neoplasms combined, benign neoplasms, and diseases of the skin and cellular tissue. The raised PMR for all malignant neoplasms combined was accounted for by raised risk for cancers of the digestive organs, urinary bladder, and the respiratory system. Further analysis showed that risks for cancers of the respiratory and digestive system were highest among those employed for more than 20 years. Analysis by year of first employment showed that workers whose employment began during or before 1950 had higher PMRs for cancers of the respiratory system and kidney. Therefore, the risk of cancer specific mortality reflected the amount of exposure and the duration of employment.

These findings are consistent with some of the previous epidemiological studies of workers in related industries. The particular exposures that might increase the risk of cancer among the engine plant workers are lubrication oils used in the machining processes. Although mineral oils are well documented as a cause of skin cancer, no deaths from skin cancer were observed in this study, although two deaths from diseases of the skin and cellular tissue were recorded. The higher PMRs for digestive cancers, especially among workers employed for 20 years, corroborate the findings of Decoufle ${ }^{8}$ Jarvholm et al, ${ }^{9}$ and Greene et al. ${ }^{10}$ Waterhouse was the first to indicate a possible risk for cancers other than those of the skin when he showed higher risks for second primary cancers of the respiratory system and upper gastrointestinal tract in a series of cases of scrotal cancer." Our study found raised PMRs for cancers of the respiratory system in workers whose employement began after 1950 and in workers who had been employed more than 20 years. Waterhouse " and Greenberg ${ }^{12}$ were the only other investigators to suggest an excess mortality from carcinoma of the lung among workers exposed to oil mist. Other studies have shown no significant increase in lung cancer in workers similarly exposed. ${ }^{8}$ y $^{13-15}$

Although it is known that the three main types of cutting fluids have been used in the engine plants, the temporal use of different types of cutting fluids was not known to the investigators. The predominant types of cutting fluids used in the engine plants before 1950 were probably insoluble and soluble mineral oils. Reported industrial hygiene measures range from less than 1 to $3.4 \mathrm{mg} / \mathrm{m}^{3}{ }^{84}$ Decoufle also reported that measurements for mineral oil mists showed geometric means of 2.4 to $5.6 \mu \mathrm{m}$, suggesting that a significant proportion of oil mist particles from non-soluble oils may be ingested. ${ }^{8}$ Studies have shown that as the diameter of airborne particles increases, the deposition rate in the upper respiratory tract increases, where clearance by cilia action is in the direction of the gastrointestinal tract. ${ }^{16}$ Synthetic fluid aerosol particles tend, however, to be smaller owing to their reduced viscosity and surface tension. Small particle diameters lead to deeper pulmonary penetration.

Mineral oil cutting fluids have been shown to be carcinogenic in animal models. ${ }^{17} 18$ The carcinogenic activity of these oils is attributed to polycyclic aromatic hydrocarbons. Bingham et al have measured four and five aromatic hydrocarbons in cutting oils $^{18}$ and the concentration of benzo(a)pyrene in mineral oils increases during use. ${ }^{19}$ Certain components and additives of mineral oils have been suggested to act as cocarcinogens. ${ }^{2021}$ Therefore, the carcinogenic potential of the soluble mineral oil based cutting fluids is well documented. In most industrial settings the synthetic formulations replaced the original mineral oils but they were not in widespread use until the mid 1950 s or later. In 1976 several investigators reported that synthetic cutting fluids contained nitrosamines, byproducts of amines and nitrites which are additives used as anticorrosion agents. ${ }^{22}$ One of the impurities found in high concentration was $\mathrm{N}$-nitrosodiethanolamine (NDEA). ${ }^{23}$ Fan et al proposed that the concentration of the nitrosamine present posed a carcinogenic hazard to all users even though the fluids are diluted 10 to 100 times before use. NDEA was found to be carcinogenic in hamsters and rats. ${ }^{24}$

In summary, the consistency of the findings in this and other studies regarding the risk of digestive cancer among workers exposed to cutting oils and the coherence with experimental data and latency characteristics of the disease corroborate the importance of occupationally related exposures. The particularly high PMR for pancreatic cancer is noteworthy. Animal data support the hypothesis that the pancreas is susceptible to transformation by carcinogenic chemicals. ${ }^{25}$ Epidemiological studies suggest that the increasing incidence of carcinoma of the exocrine pancreas in the United States may reflect chemical carcinogenesis. ${ }^{26} \mathrm{~A}$ recent study of the incidence of cancer of the pancreas in Los Angeles showed a proportional incidence ratio of 130 for white male machinists. ${ }^{27}$

The risk of lung cancer associated with exposure to cutting fluid mist remains controversial and many conflicting results have been reported. Most of the studies conducted to date have evaluated the risk to workers exposed primarily to oil based cutting 
fluids. There have been no specific epidemiological studies of the long term health effects of water based synthetic cutting fluids. For example, the most comprehensive study conducted to date ${ }^{8}$ followed up the cohort of workers only to 1968 , which is, at most, only 15 years after initial exposure to synthetic cutting fluids. Our finding that workers whose employment began after 1950 have a slightly raised and significant PMR for cancers of the respiratory system cannot be interpreted in the absence of information regarding changes in the composition of the materials to which the workers were exposed.

The method used in this study has been reviewed extensively and its use in estimating cause specific mortality risk to generate hypotheses is well documented. ${ }^{28-31}$ These findings, however, must be judged in the context of the limitations inherent in the method. For instance, workers employed for more than 10 years and therefore vested in union and company benefit programmes were selected for inclusion in the study to assure identification of number of deaths among a defined population. All deaths among individuals who terminated employment before being vested in the benefit programme were not entered in the union records and could not be included in the study. Several investigators have shown that mortality is higher among workers who leave an industry than those who remain until retirement. ${ }^{32} 33$

Also, PMRs may be inflated for certain causes of death when the overall mortality of a study group is lower than the comparison or standard population. In other words, if a strong healthy worker effect is operating, some PMRs may be overestimated, in particular those that would be affected by "health" selection. Another limitation of this study is that the specific employment experiences that would permit identification of exposure were not available for each subject. Assumptions about exposure were based only on the knowledge of the processes within the individual plants. In addition, individual information on personal risk factors such as smoking and alcohol consumption was not available. Despite these limitations, PMR studies based on deaths ascertained through employee benefit programmes have shown that PMRs among long term employees may be as valuable for occupational mortality surveillance as SMRs. ${ }^{30}$

This study was intended as an exploratory investigation of the mortality patterns of auto workers employed in a large manufacturing complex. Although the limitations of the study design preclude inferences regarding cause and effect relationships, the statistical associations indentified suggest hypotheses that should be tested in studies requiring the provision of data specific to employer records.
Therefore, a nested case control study of workers employed in the engine plant is indicated to investigate if the excess digestive and lung cancers are related to exposure to cutting fluids or other chemicals, or a combination of these.

This research was supported in part by grants from the Health Research Council of New York State Health Planning Commission and the City of Buffalo, PAL Special Projects Administration. We thank Mr Thomas Fricano, assistant director, Region \#9, United Auto Workers, for his guidance and support and Michael Silverstein, of the International United Auto Workers, for his advice and critical comments on an initial draft of this paper. We especially thank Mr Phillip Quickenton, assistant director of health statistics, New York State Department of Health, and his staff. Also, we acknowledge the technical writing help of Frances $S$ Sherwin and the masterful preparation of the manuscript by JoMarie Rizzo.

\section{References}

' Monson RR. Analysis of relative survival and proportional mortality. Comput Biomed Res 1974;7:325-32.

${ }^{2}$ Decoufle P, Thomas TL, Pickle LW. Comparison of the proportionate mortality ratio and standardized mortality ratio risk measures. Am J Epidemiol 1980;111:263-9.

${ }^{3}$ Kaminski R, Geissert KS, Pacy E. Mortality analysis of plumbers and pipefitters. JOM 1980;22:183-9.

${ }^{4}$ International classification of diseases. 8th rev. (Adapted for use in the US 1968.) Washington: US Department of Health, Education, and Welfare, Public Health Service, National Center for Health Statistics, 1968. (Publication No 1693.)

5 Redmond CK, Wiland HS, Rockette HS, Sass R, Weinberg G. Long term mortality experience of steelworkers. Washington: US Government Printing Office, 1981. (DHHS (NIOSH) publication No 81-120.)

- Tola S, Koskela R, Herberg S, Jarvinen E. Lung cancer mortality among iron foundry workers. JOM 1979;21:753-60.

${ }^{7}$ Egan-Baum E, Miller BA, Waxweiller RJ. Lung cancer and other mortality patterns among foundrymen. Scand J Work Environ Health 1981; 7:147-55.

${ }^{8}$ Decoufle P. Further analysis of cancer mortality patterns among workers exposed to cutting oil mists. J Natl Cancer Inst 1978;61: 1025-30.

9 Jarvholm B, Lillienberg L, Sallsten G, et al. Cancer morbidity among men exposed to oil mist in the metal industry. JOM 1981;23:333-7.

${ }^{10}$ Greene MH, Hoover RN, Eck RL, Fraumeni JF. Cancer mortality among printing plate workers. Environ Res 1979;20:66-73.

"Waterhouse JAH. Lung cancer and gastro-intestinal cancer in mineral oil workers. Ann Occup Hyg 1972; 15:43-4.

12 Greenberg M. A proportional mortality study of a group of newspaper workers. Br J Ind Med 1982;29:15-20.

13 Ely TS, Pedley SF, Hearne FT, Stille WT. A study of mortality, symptoms and respiratory function in humans occupationally exposed to oil mist. JOM 1970;12:253-61. 
${ }^{14}$ Goldstein DH, Denoit JN, Tyroler HA. An epidemiologic study of an oil mist exposure. Arch Environ Health 1970;21:60)(1-3.

is Pasternack B, Ehrlick L. Occupational exposures to an oil mist atmosphere. Arch Environ Health 1972; 25: 286-94.

in National Academy of Sciences. Committee on biological effects of air pollution: particulate polycyclic organic matter. Washington, DC: US Government Printing Office, 1975.

${ }^{17}$ Gilman JP, Vesselinovitch SD. Cutting oils and squamous cell carcinoma, II. An experimental study of the carcinogenicity of two types of cutting oils. Br J Ind Med 1955;12:244-8.

${ }^{1 *}$ Bingham E. Horton AW, Tye R. The carcinogenic potency of certain oils. Arch Environ Health 1965; 10:449-51.

${ }^{14}$ Thony C, Thony J, La Fontaine M, Linasset JC. Polycyclic aromatic hydrocarbon concentration of some mineral oils. Archives des Maladies Professionelles de Médecine du Travail et de Securité Sociale 1975;36:37-52.

¿" Horton AW, Bingham EL, Burton MJG, Tye R. Carcinogenesis of the skin III. The contribution of elemental sulfur and of organic compounds. Cancer Res 1965;25: 1759-63.

" Kipling MD, Waldron HA. Polycyclic aromatic hydrocarbons in mineral oil, tar, and pitch, excluding petroleum pitch. Prev Med 1976:5:262-78.

$\because$ US Department of Health, Education, and Welfare. Public Health Service National Institute for Occupational Safety and Health. Nitrosamines in cuttting fuids. (Current Intelligence Bulletin, 15.) Rockville, Maryland: DHEW, 1976. (DHEW (NIOSH) publication No 78-127, 1976.)

${ }^{23}$ Fan TY, Morrison J, Roundbehler DP, et al. N-nitrosodiethanolamine in synthetic cutting fluids: a part-perhundred impurity. Science 1977:196:70-1.
${ }^{24}$ Hilfrich J, Schmeltz I, Hoffman D. Effects of N-nitrosodiethanolamine and 1,1-diethanolhydraxine in Syrian golden hamsters. Cancer Lett 1977; 4:55-60.

${ }^{25}$ Woolley PV, Pinsky SD. Binding of N-nitroso carcinogens in pancreatic tissue. Cancer 1981;47:1485-9.

${ }^{26}$ Longnecker DS. Environmental factors and diseases of the pancreas. Environmental Health Perspect 1977; 20:105-12.

27 Mack TM, Paganini-Hill A. Epidemiology of pancreas cancer in Los Angeles. Cancer 1981;47:1474-83.

2* Redmond CK, Breslin PP. Comparison of methods for assessing occupational hazards. JOM 1975;17:313-7.

${ }^{24}$ Kupper LL, McMichael AJ, Symons MJ, Most BM. On the utility of proportionate mortality analysis. J Chron Dis 1978;31:1522.

${ }^{30}$ Waxweiller RJ, Haring MK, Leffingwell SS, Halperin WH. Quantification of differences between proportionate mortality ratios and standardised mortality ratios. In: Banbury Report, No 9. Quantification of occupational cancer. New York: Cold Spring Harbor Laboratory, 1981:379-89.

${ }^{31}$ Beaumont JJ, Leet TL, Okun AH. Occupational data sets appropriate for proportionate mortality ratio analysis. In: Banbury Report, No 9. Quantification of occupational cancer. New York: Cold Spring Harbor Laboratory, 1981:391-411.

32 Fox AJ, Collier PF. Low mortality rates in industrial cohort studies due to selection for work and survival in industry. $\mathrm{Br} J$ Prev Soc Med 1976:30:225-30.

${ }^{33}$ Gilbert ES. Some confounding factors in the study of mortality and occupational exposures. Am J Epidemiol 1982;116:11788 . 